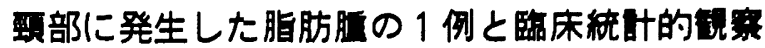

\author{
鈴木三郎・塩入重彰・木野孔高・镸谷川和樹 \\ 秋元康志・泉祐萃・田中信幸・佐䠌建夫

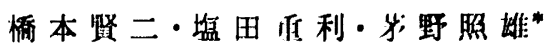

\section{Lipoma of the neck: Report of a case and review of 33 cases in our department}

\author{
Saburou SuzukI - Shigeaki ShorrI - Kouji Kino - Kazuki Hasegawa \\ Yasushi Акıмотo - Yuko Izumi - Nobuyuki Tanaka - Tateo Sato \\ Kenji Hashimoto - Shigetoshi Shioda - Teruo Kayano*
}

\begin{abstract}
A case of relatively large lipoma of the right neck is reported and thirty-three cases of lipomas treated in our department from 1965 to 1986 are reviewed.

A 64-year-old man was admitted to our department complaining of a right neck swelling. The preoperative diagnosis was lipoma based on clinical findings as well as the image findings of CT scan and echogram. The tumor was excised through a cervical skin incision under general anesthesia. It lied between the platysma and the superficial layer of the cervical facia. The enucleated yellow and soft specimen was $12 \times 7 \times 6.5 \mathrm{~cm}$ in size, and covered with a thin fibrous capsule. The histopathological diagnosis was lipoma. The prognosis has been good for about one year. From our statistical study the distribution by site of 33 lipomas is as follows: eleven cases in the cheek, five in the lower lip, five in the tongue, three in the submandibular region, two in the gingiva, the floor of the mouth, the soft palate, the preauricular portion each other and one in the neck. Males are more affected than females. $76 \%$ of the patients are over 40 years of age.
\end{abstract}

Key words: lipoma, neck, statiscal study

緒言

脂肪腫は，成熟した脂肪組織の增殖から成る良性腫陽 であり，口腔領域では比較的少ないとされている。一

東京医科歯科大学齿学部第 1 口腔外科学教室 （主任：塩田重利教授）

* 東京医科歯科大学齿学部口腔病理学教室 （主任：山本 綮教授）

The First Department of Oral Surgery, Faculty of Dentistry, Tokyo Medical and Dental University (Chief: Prof. Shigetoshi Shioda)

* Department of Oral Pathology, Faculty of Dentistry, Tokyo Medical and Dental University (Chief: Prof. Hajime Yamamoto)

受付日：昭和62年 1 月 26 日
方, 頸部には全身の脂肪腫の約 $10 \% か ゙$ 発生すると言われ 好発部位の一つである゙が，われわれ口腔外科において は経験することはまれである．今回，右側顓部に発生し た比較的大きな脂肪腫を経験したのでその概要ととも に, 1965年〜1986年までの22年間の当科自験脂肪腫33症 例について臨床的検討を加光報告する。

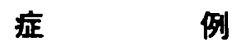

患 者: 64歳 男性.

初診：1985年11月日。

主 訴: 右側饋部の畽脹.

既往歴：30年前，急性腎炎。

家族歴：特記事項なし.

現病歴 : 䄪 12 年前, 右顎下部の無痛性, 柔軟な䮭卵大 


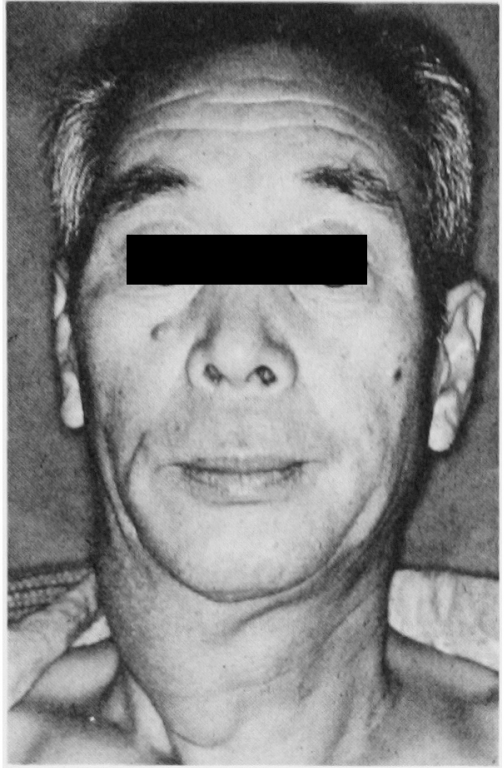

写索 1 A 初部時正貌

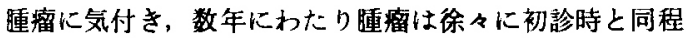
度まて増大したか，発育が停止したため放固していた。 しばらく前から腫穜が気になり始め，当科を受診した。

現症

全身所見，体格は中等度で，栄養は良好であり，全身 的に特に異常は認められなかった。

局所所見：顔貌は左右非対称で，右䋶下部から形部に か外，䄪 $10 \times 7 \mathrm{~cm}$ 大の境界ほほ明瞙で柔軟な無痛性腫 痛が認められ，同部の皮苗色はやや赤味を呈していた （写直 $1 \mathbf{A} 、 \mathbf{B}$ ). 所属リンパ節所見には特に異常は認め られなかった。

口腔内所見：特記事項はなし.

$\mathbf{X}$ 楾検查所見：単純 $\mathbf{X}$ 線写真所見では特記事項はな

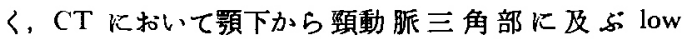
density mass が存在し, density より脂肪組織が考えら れた（写真 2 )。

エコー所見：右頻下部よりオトガイ下部にかけて，境 界比較的明瞙で辺縁平滑なやや低エコーの畽率が認めら れ, 内部ェューは不均一点状の微細なェューよりなり， 一部高エコーの部分が存在していた（写真了）.

臨床検查所見 : $\mathrm{LDH} 485 \mathrm{mU} / \mathrm{ml}$, トリグリセライド $609 \mathrm{mg} / \mathrm{d} l$ を示したが，その他に異常所見は認められな かった.

臨床診断：右頸部脂肪尰の疑い

処置ならびに経過：1986年 1 月口日全麻下に頸部䏢線 に添い、皮㙛切開を加えたところ，広頸筋直下に黄色，采

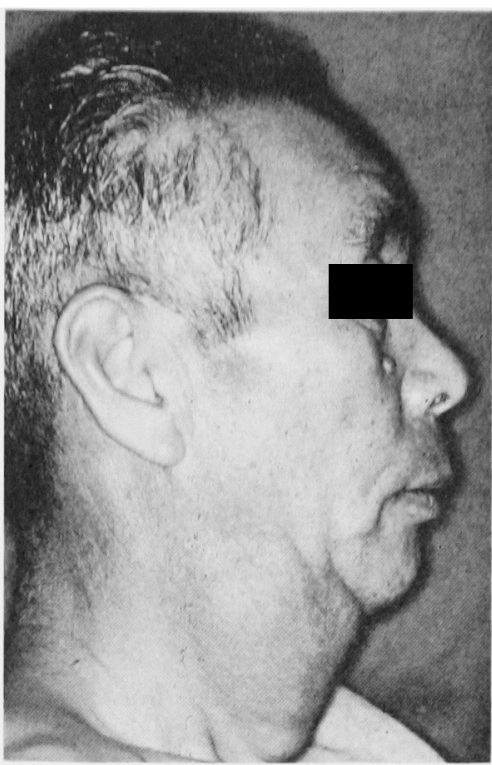

写兵 1 B 初祅時侧貌

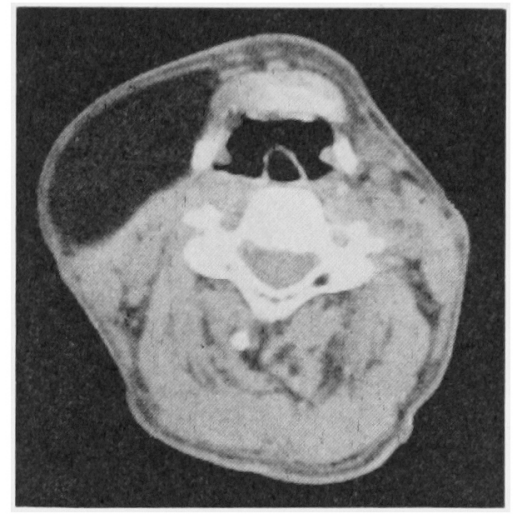

写真 2 CT 像

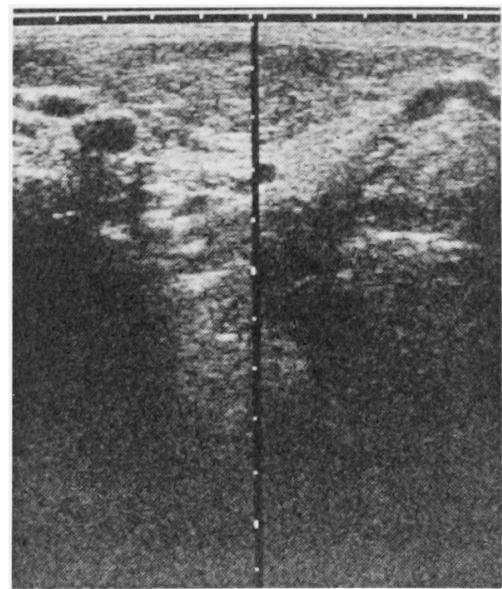

写直 3 ェーー像 


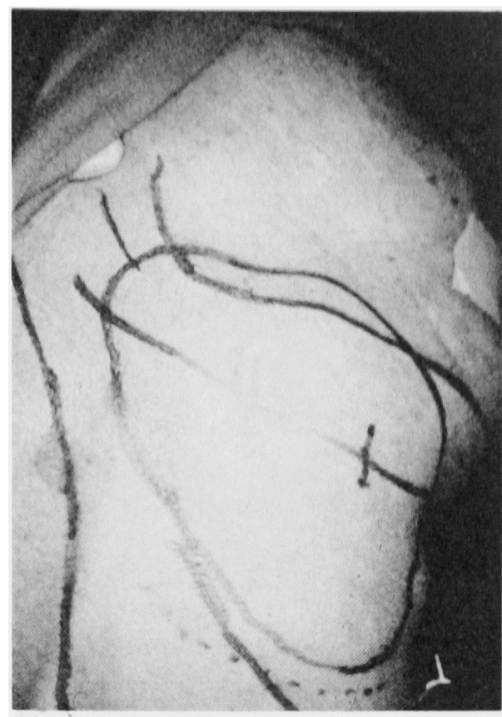

写卉 4 A 深中写

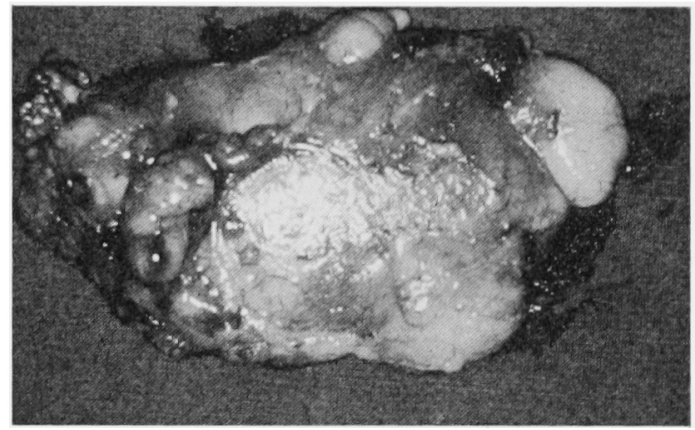

军卉 5 摘出物

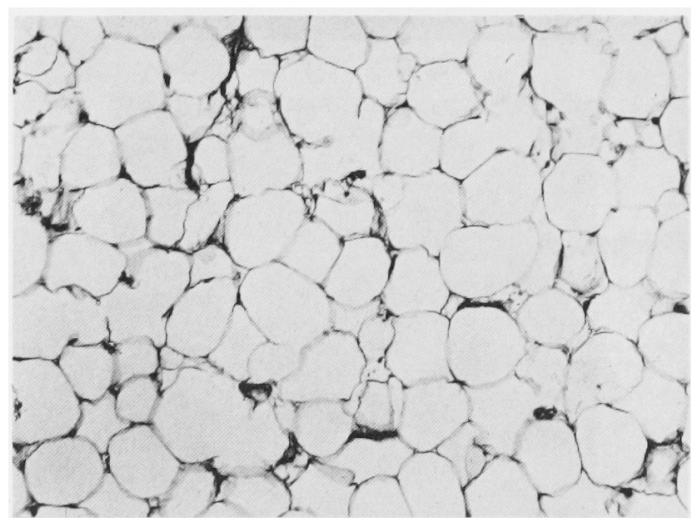

写真 6 病理組織像 (1)

軟な腫瘤が認められ，ほぼ頸筋膜浅葉上で䫑下腺外側か ら頸動脈三角内より鈍的に剝離し，一塊として摘出し た。なお耳下眿下極部は豩離困難のため，眿組織を一部

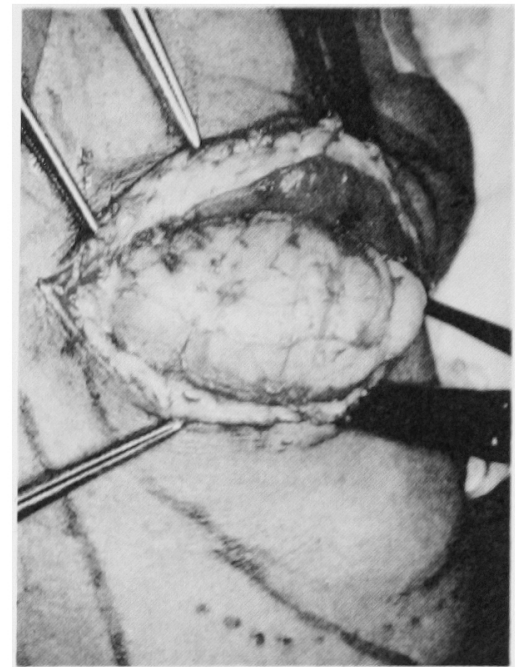

军卉 4 B 術中军真

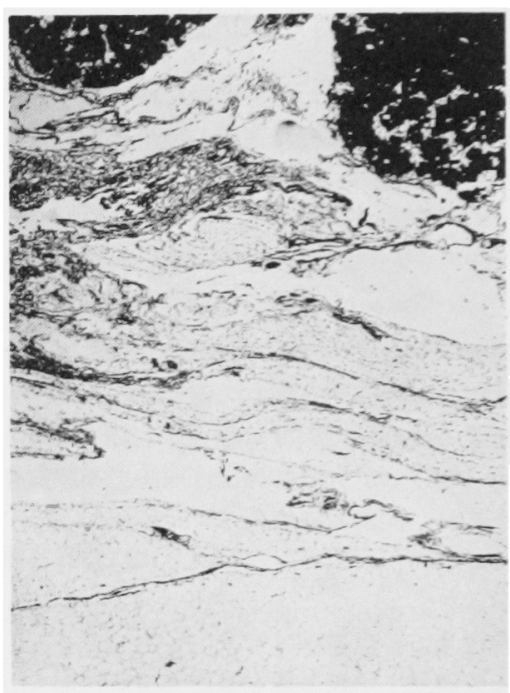

写高 7 病理組機像 (2)

切除した，顎下腺とは，制崔が容易であり䈍着は認めら れなかった（写真 4 A，B）。術後経過は良好で，術後 1 年を释た現在，再発は認められない。

摘出物所見: 摘出物は, 薄い線維性被臨で被覆されて おり分葉状を呈し，大きさは $12 \times 7 \times 6.5 \mathrm{~cm}$ であった (写真 5 ).

病理組織学的所見：細い結合組織の隔壁のある小葉構 造を示す成熟した脂肪組織の増生物で，脂肪芽細胞は認 められなかった（写声 6 ）。一部に耳下腺組織が認めら れるが，重湯とは薄い線維性被膜で一層境されていた (写直 7 ). 


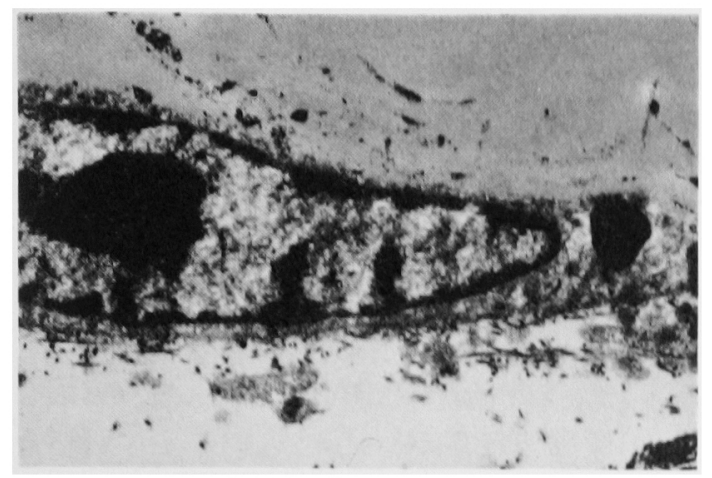

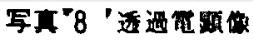

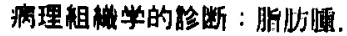

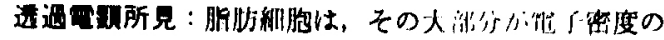

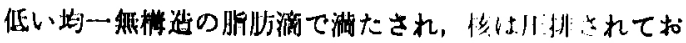

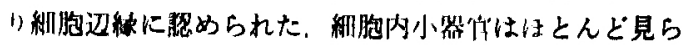

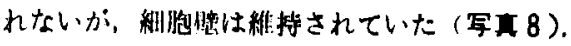

\section{考 事}

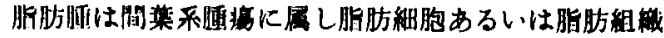

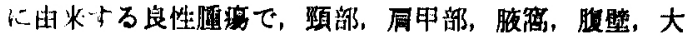
腿部などの皮下脂肪縕織にみられ，まれに呼吸器，消化 器の粘膜，随意筋の㬳膜にるみられるとされている。

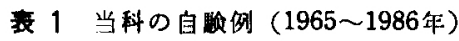

\begin{tabular}{|c|c|c|c|c|c|}
\hline 症例 & 年䗆 & 性别 & 発生部位 & 病愊期間 & 大きさ $(\mathrm{mm})$ \\
\hline 1 & 61 & 男 & 下宠粘膜 & 10年 & $20 \times 20$ \\
\hline 2 & 32 & 男 & 左口底 & 2 年 & $15 \times 15$ \\
\hline 3 & 20 & 女 & 两侧耳介前部 & 15年 & $6 \times 6$ \\
\hline 4 & 37 & 男 & 左煩粘膜 & 10 年 & $20 \times 20$ \\
\hline 5 & 73 & 男 & 右下影舌側肉 & 4 名月 & $5 \times 5 \times 4$ \\
\hline 6 & 31 & 女 & 右煩部 & 4 只 & $70 \times 50$ \\
\hline 7 & 62 & 男 & 左舌紜 & 2 か月 & $15 \times 15$ \\
\hline 8 & 69 & 女 & 右口底 & 3 か月 & $40 \times 30$ \\
\hline 9 & 71 & 女 & 右下居粘膜 & 1 か月 & $20 \times 10$ \\
\hline 10 & 27 & 女 & 右煩粘膜 & 6 年 & $35 \times 35$ \\
\hline 11 & 56 & 男 & 右舌粶 & 1 か月 & $6 \times 6$ \\
\hline 12 & 41 & 男 & 左煩粘瞙 & 5 年 & $20 \times 15 \times 10$ \\
\hline 13 & 71 & 男 & 左頓粘膜 & 1.5 年 & $26 \times 9$ \\
\hline 14 & 67 & 女 & 左下額頓側歯肉 & 6 か月 & $15 \times 10$ \\
\hline 15 & 36 & 男 & 右軟口蓋 & 6 只 & $7 \times 7$ \\
\hline 16 & 52 & 女 & 下唇粘瞙 & 6 年 & $6 \times 6$ \\
\hline 17 & 60 & 女 & 左煩粘膜 & 12年 & $30 \times 40$ \\
\hline 18 & 57 & 男 & 右煩部 & 2 年 & $60 \times 40$ \\
\hline 19 & 29 & 女 & 左耳介前部 & 1 年 & $18 \times 26$ \\
\hline 20 & 45 & 男 & 左下崖粘膜 & 3 年 & $15 \times 15$ \\
\hline 21 & 47 & 男 & 左類下部 & 6 か月 & $38 \times 18 \times 15$ \\
\hline 22 & 54 & 男 & 左下唇粘膜 & 4 年 & $15 \times 20$ \\
\hline 23 & 58 & 女 & 左頓粘膜 & 1 週 & $15 \times 15$ \\
\hline 24 & 49 & 女 & 右舌緑 & 3 か局 & $15 \times 22$ \\
\hline 25 & 43 & 女 & 右舌背 & 10 年 & $5 \times 5$ \\
\hline 26 & 47 & 男 & 左影下部 & 1 年 & $35 \times 35$ \\
\hline 27 & 39 & 男 & 軟口蓋正中 & 2 か月 & $23 \times 13$ \\
\hline 28 & 56 & 男 & 右舌縁 & 2 加月 & $7 \times 5$ \\
\hline 29 & 55 & 男 & 右煩部 & 1 年 & $37 \times 50$ \\
\hline 30 & 49 & 男 & 左頓粘膜 & 15年 & $54 \times 30 \times 10$ \\
\hline 31 & 44 & 男 & 右額下部 & 2 過 & $60 \times 40$ \\
\hline 32 & 70 & 男 & 右頓粘膜 & 自覚せず & $20 \times 17 \times 9$ \\
\hline 33 & 64 & 男 & 右顥部 & 12 年 & $120 \times 70 \times 65$ \\
\hline
\end{tabular}




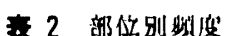

\begin{tabular}{|c|c|c|c|}
\hline 部 位. & 男 & 女 & 计 \\
\hline 煩 部 & 7 & 4 & 11 \\
\hline 下 婹 & 3 & 2 & 5 \\
\hline 呦 肉 & 1 & 1 & 2 \\
\hline 口 践 & 1 & 1 & 2 \\
\hline$r_{i}$ & 3 & 2 & 5 \\
\hline 忺口篮 & 2 & 0 & 2 \\
\hline 䫁下部 & 3 & 0 & 3 \\
\hline 頙 部 & 1 & 0 & 1 \\
\hline その他 & 0 & 2 & 2 \\
\hline
\end{tabular}

表 3 年粉・性别斯度

\begin{tabular}{c|c|c|c}
\hline 年 & 男 & 女 & 都 \\
\hline $20 \sim 29$ & 0 & 3 & 3 \\
$30 \sim 39$ & 4 & 1 & 5 \\
$40 \sim 49$ & 6 & 2 & 8 \\
$50 \sim 59$ & 5 & 2 & 7 \\
$60 \sim 69$ & 3 & 3 & 6 \\
$70 \sim$ & 3 & 1 & 4 \\
\hline 諧 & 21 & 12 & 33 \\
\hline
\end{tabular}

Anderson $^{2)}$ やShafer ら3)は，頸部は好発部位であると し，また遠城寺ら" は，脂肪腫1，614例中，頸部には166 例見られたとしている．頸部腫瘤のうち脂肪腫の占める 割合は，植草ら ${ }^{4)} は 13$ 年間に284例中23例，藤本ら ${ }^{5)} 5$ 年間に13例見られたとしている.

当教室の1965年から1986年の22年間における脂肪腫の 一覧を表 1 に示す，口腔内外を合わせて33症例であり， 口腔領域における発生率は，石川 ${ }^{6)}$ いらよ5に，かつ て考えられていたはどまれなものではないようである。

口腔領域における部位別では，Hatziotis?), MacGre-

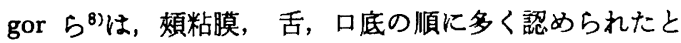
述べて扣り，自験例でも頓部が11例と最も多く，次いで 舌，下唇に各 5 例ずつ認められた。碩部では，䫑下部に 3 例見られるが，中頚部以下の側頸部は，本症例のみで あった（表 2）。これは口腔外科といら特殊性であろう.

年龄については，40歳以上に多いといわれており，当 科自験例では20歳から73歳の各年龄にみられるが，40歳 代 ( 8 例) 50 歳代 ( 7 例) 60 歳代 (6 例) の順に多く認 められ，平均年龄は50.7歳であった（表 3）.

性差については，報告者により一定ではないが石川 は男性にやや多いが著変はないとしており，当科におい ては，男性に多く認められた（表了）.

病悩期間については一般に長期に及ぶとされ，根本 ら9)の，42年間にわたる舌の 1 例の報告があるが，当科
においては 1 年以内が18例と約半数を占めるものの, 1 年以上も15例であり，その3ち5 年以上の应例が約 $1 / 3$

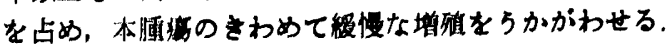

大きさについては，大きいるのでは Smith'10)による11 $\times 9 \times 7 \mathrm{~cm}$ 大の舌の 1 例，木下ら ${ }^{11}$ K上る $16 \times 5 \times 5 \mathrm{~cm}$

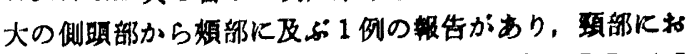

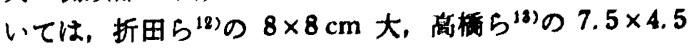

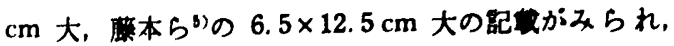
これらの報告例と比粉すると本症例は比效的大きなるの と考えられる. 当科自除33应例では， $2 \mathrm{~cm}$ 以下か18例， $4 \mathrm{~cm}$ 以下が 9 例で, $4 \mathrm{~cm}$ より大きいむのは6例であ りそのらち本症例を除くと，箕部と願下部であった。

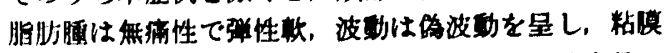
值下に存在すれば英色の外得を星し診断は比教的容易で あるが，存在部位によっては因败である，自涘例33症例

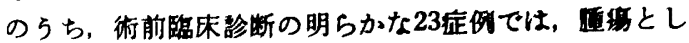

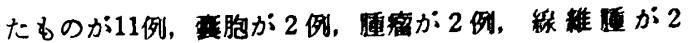

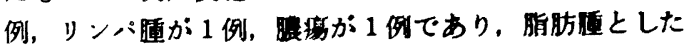

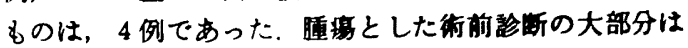
脂肪腫を第一に策ったるのと推測される，本症缏では， 臨床経過, 虽床所見, ェコークラムならびに CT 所見 から脂肪畽と診断したが，特に両画像診断は有用であっ た。

治㞠法は全摘出術であり, 予後は全摘出すれば再発す ることはないといわれている，本症例では，尰㻉の一部 か耳下腺下樰と㯺着した状態にあったためこの部分を含 めて摘出したが, 病理組絨学的に薄い線維性被谟を介し て耳下眿組織に移行しているとの所見が得られたので， 必要な処膡であったと考えられる.

\section{結語}

64歳男性の頚部に発生した比較的大きな脂肪尰の 1 例 を経験したので，その概要を報告するととるに，1965年 〜1986年の 22 年間の当科自呀脂肪腫33例についても険討 を加えた。

なお，本論文の要旨は，第 135 回日本口腔外科学会関 東地方会（1986年6月，横浜）において報告した。

\section{引用文 献}

1）遠城寺宗知，岩奇 宏，他：わが国に括ける良性 軟部組織腫瘍。癌の臨床 20: 594-609 1974.

2) Anderson, W.A.D.: Pathology I. 6 th Ed, Mosby Co, St Louis, 1971, p 573-574.

3) Shafer, W.G., Hine, M.K., et al.: A Textbook of Oral Pathology. 4th Ed, Saunders Co, Philadelphia, 1983, p 152-153.

4) 植草実, 米山桂八, 他 : 頚部腫瘤の臨床診断. 
外科馀 13: 1123-1129 1971.

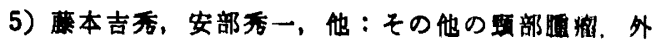
科馀 13: 1130-1136 1971 .

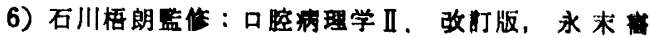
店，京都，1982，570-572頁。

7) Hatziotis, J. Ch.: Lipoma of the oral cavity. OS OM OP 31: 511-524 1971.

8) MacGregor, A.J. and Dyson, D.P.: Oral lipoma. OS OM OP 21: 770-776 1966.

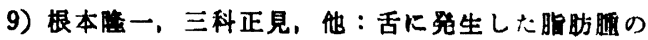
1 例。 日外誌 32：2390-2395 1986.
10) Smith, F.: Lipoma of the tongue. JAMA 108: 522-523 1937.

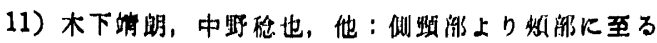

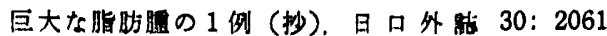
1984.

12) Orita, Y., Kawata, M., et al.: A case of lipoma in the deep part of neck. KAWASAKI MED J 10: 207-210 1984.

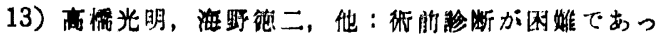

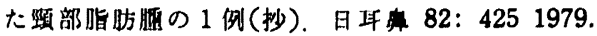

